\title{
Peningkatan Efisiensi Kerja Guru Melalui Pembuatan Aplikasi Rapor Berbasis Komputer
}

\author{
Romy Budhi Widodo ${ }^{1}$, Mochamad Subianto ${ }^{2}$, Grace Imelda ${ }^{3}$ \\ Universitas Ma Chung Malang ${ }^{1,2}$; SMP YPK Malang ${ }^{3}$ \\ romy.budhi@machung.ac.id, mochamad.subianto@machung.ac.id
}

\begin{abstract}
The domain of the activity is technology for the society whereas the focus is practical computer science for the society. The background of our activity is based on the needs of YPK junior high school in Malang city, Indonesia. The school need to develop computer-based school report card and also daily grade card for teachers. The method for software/application development is spiral model which consist of the cycle of system identification, risk analysis, and enhancement of the prototype to be an operational prototype. Evaluation of the product was based on the Computer System Usability Questionnaire (CSUQ) from IBM. The CSUQ using 5 scale of Likert scale contains three categories: 1) system usefulness (SYSUSE), 2) information quality (INFOQUAL), and 3) interface quality (INTERQUAL). The mean rank's result in order from the greatest to the lowest is SYSUSE, INTERQUAL, and INFOQUAL, respectively. It was reported that SYSUSE category was superior to INFOQUAL $(U=3369.5, p=0.0005)$. Overall, the user satisfaction score is $78.4 \%$, which is in the "worthy" category.
\end{abstract}

Keywords: School report card; CSUQ; Spiral model.

\begin{abstract}
Abstrak
Kegiatan yang dilakukan berada dalam domain ipteks bagi masyarakat, dengan fokus bidang ilmu komputer untuk masyarakat. Kegiatan dilatarbelakangi oleh kebutuhan yang dirasakan oleh Sekolah Menengah umum Pertama Yayasan Pendidikan Kristen Jawa Timur (SMP YPK, Malang). Sekolah membutuhkan pendampingan dalam mengotomatisasi laporan nilai harian dan rapor semester. Tujuan kegiatan adalah menghasilkan produk aplikasi berbasis komputer, yaitu otomasi nilai harian dan rapor semester siswa SMP YPK, Malang. Metode yang digunakan dalam pengembangan perangkat lunak adalah spiral model yang merupakan siklus identifikasi, analisis risiko, dan peningkatan tingkat purwarupa software sehingga menjadi purwarupa operasional. Evaluasi terhadap produk dilakukan dengan mengadopsi angket CSUQIBM (Computer System Usability Questionnaire). Hasil evaluasi produk menggunakan CSUQ terbagi menjadi tiga kategori evaluasi yaitu: system usefulness (SYSUSE), information quality (INFOQUAL), dan interface quality (INTERQUAL). Urutan mean rank dari yang tertinggi ke rendah adalah SYSUSE, INTERQUAL, dan INFOQUAL. Dengan menggunakan angket dengan Likert scale skala 5, diperoleh hasil bahwa aplikasi yang dibangun memiliki tingkat SYSUSE yang lebih besar dan berbeda signifikan dari kategori INFOQUAL $(U=3369.5, p=0.0005)$. Sedangkan skor kepuasan pengguna terhadap aplikasi adalah dalam kategori layak (78.4\%).
\end{abstract}

Kata Kunci: Rapor; CSUQ; Model spiral. 


\section{A. PENDAHULUAN}

Sekolah menengah umum pertama dari Yayasan Pendidikan Kristen Jawa Timur yaitu SMP YPK, Malang; memiliki visi dan nilai sebagai berikut:

1) Visi sekolah: menjadi sekolah kehidupan (school for life) yang menyiapkan generasi yang memiliki relasi yang baik dengan Tuhan, gemar belajar, berwawasan ilmu pengetahuan, teknologi, enterpreneur, dan lingkungan serta terpanggil sebagai agen transformasi masyarakat; 2) Nilai/filosofi: kepemimpinan, pembentukan karakter, keterampilan berpikir inovatif, enterpreneurship, pengetahuan multikultural, dan keterampilan hidup.

Seiring perkembangan waktu dengan bertambahnya jumlah siswa, dan perkembangan teknologi komputer. Maka sistem pengarsipan data siswa yang berbasis komputer beserta nilainya sangatlah diperlukan. Meskipun sistem semacam ini telah ada di SMP tersebut namun peningkatan diinginkan seiring kurikulum 2013. Ketergantungan pada perhitungan manual perlu bertahap dialihkan ke bentuk digital, yang mengakomodasi sistem penilaian di kurikulum 2013 (Siswanto, 2017).

Berdasarkan analisis kebutuhan yang dilakukan melalui wawancara kepada kepala sekolah disertai bukti-bukti berupa: form nilai harian dan buku rapor semesteran; maka kegiatan yang diperlukan adalah membuat perangkat lunak/aplikasi untuk memudahkan guru mata pelajaran menghitung nilai siswa. Demikian pula juga diperlukan aplikasi rapor semesteran yang digunakan oleh wali kelas VII, VIII, dan IX.

\section{B. PELAKSANAAN DAN METODE}

Metode pelaksanaan kegiatan adalah difusi ipteks, dimana pengembang/pelaksana menghasilkan produk aplikasi bagi sekolah tersebut. Pembuatan aplikasi ini menggunakan metode spiral yang dalam teori dikembangkan oleh Barry Boehm (Boehm, 1988). Produk yang dihasilkan adalah aplikasi rapor semester dan pencatatan nilai harian sesuai Kurikulum 2013 seperti dalam (Siswanto, 2017). Pengembangan kurikulum 2013 sendiri menekankan prinsip bahwa peserta didik berada pada posisi sentral dan aktif dalam belajar, sehingga evaluasinya untuk mengetahui dan memperbaiki pencapaian kompetensi siswa. Instrumen penilaian hasil belajar adalah alat untuk mengetahui kekurangan yang dimiliki setiap peserta didik atau sekelompok peserta didik, seperti tertuang dalam (Kemendikbud, 2012; Sinambela, 2013).

Model spiral merupakan gabungan antara model waterfall dan model iterative. Inti dari model Spiral adalah setiap putaran/fase-nya diawali dengan perencanaan desain dan diakhiri dengan pengguna memberikan masukan atau review. Demikian putaran dilakukan terus hingga diperoleh produk yang siap dioperasikan. Setiap putaran mewakili suatu pekerjaan, secara umum ada empat pekerjaan yang berurutan, yaitu: 1) Pengembangan konsep, 2) Pengembangan sistem, 3) Peningkatan kinerja sistem, 4) Perawatan sistem. Fasefase dalam tiap pekerjaan tersebut disertai aktifitasnya seperti pada Tabel 1. Gambar 1 menunjukkan model spiral dari pengembangan aplikasi. 
Tabel 1. Fase Pengembangan dan Aktifitas

\begin{tabular}{ll}
\hline \multicolumn{1}{c}{ Fase } & \multicolumn{1}{c}{ Aktifitas } \\
\hline Perencanaan & $\begin{array}{l}\text { Memahami kebutuhan, } \\
\text { mencatat spesifikasi yang } \\
\text { diinginkan, penjadwalan. }\end{array}$ \\
\hline Analisis & $\begin{array}{l}\text { Identifikasi kemungkinan } \\
\text { resiko }\end{array}$ \\
\hline Rekalahan aplikasi. \\
\hline Pengembangan aplikasi \\
& dan pengujian bersama \\
& guru. \\
\hline Evaluasi fitur aplikasi yang \\
& Sedang dibuat oleh guru. \\
& Kembali ke perencanaan \\
& untuk siklus berikutnya. \\
\hline
\end{tabular}

Evaluasi hasil aplikasi digunakan pengukuran usability. Pengukuran usability diperlukan baik pada produk hardware maupun software. Pengukuran usability tergolong sulit sebab karakteristiknya multidimensi. Melalui pengukuran usability maka pengembang dapat menilai produk software yang dihasilkannya. Pengukuran usability termasuk kedalam bidang human factor yang bertujuan mengukur mental workload.

Pengukuran mental workload dibedakan menjadi dua jenis yaitu pengukuran objektif dan subjektif. Penggunaan pengukuran objektif umumnya digunakan untuk mengevaluasi peningkatan produktifitas dari sistem yang baru, sedangkan pengukuran subjektif lebih menekankan pada kepuasan pengguna (user satisfaction). Pengukuran subjektif lebih baik daripada objektif sebab lebih mudah, lebih cepat, dan tidak mahal (Lewis, 1995).

Beberapa jenis angket telah diuji coba oleh IBM, salah satu yang sesuai untuk keadaan dalam pengabdian masyarakat ini adalah The Computer System Usability Questionnaire (CSUQ). Penggunaan CSUQ juga telah diadopsi untuk negara yang menggunakan bahasa selain Bahasa Inggris, seperti dalam (Erdinç \& Lewis, 2013). Bahkan penggunaan CSUQ untuk menilai/mengevaluasi persepsi pengguna komputer masih diakui hingga saat ini, disejajarkan dengan instrmen lain, seperti dituangkan dalam (Lewis, 2018).

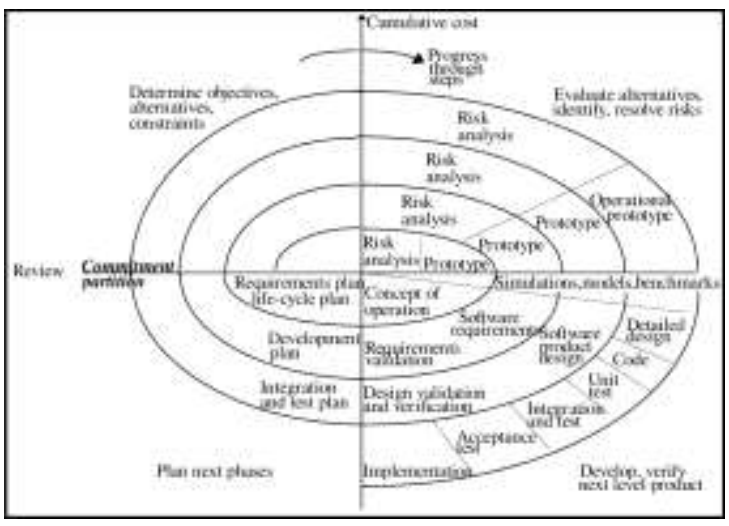

Gambar 1. Model Spiral Pengembangan Aplikasi (Boehm, 1988)

CSUQ terdiri atas 19 pertanyaan dengan menggunakan Likert scale dengan 5 skala ) (Lewis, 1995). Pertanyaan-pertanyaan pada CSUQ sesuai untuk pengujian lapangan dalam arti penggunaan aplikasi oleh pengguna.

Pertanyaan-pertanyaan pada CSUQ terdiri atas beberapa bagian/kelas, yaitu: 1) OVERALL (nomor 1 hingga 19); 2) SYSUSE (nomor 1 hingga 8); 3) INFOQUAL (nomor 9 hingga 15); 4) INTERQUAL (nomor 16 hingga 18). Dimana OVERALL adalah keseluruhan pertanyaan; SYSUSE (system usefulness) adalah kebergunaan sistem bagi pengguna dalam menyelesaikan tugasnya; INFOQUAL (information quality) adalah fitur-fitur di software yang memberikan pesan bagi pengguna dalam mengoperasikan software ataupun saat terjadi kesalahan; INTERQUAL (interface quality) adalah pertanyaan yang ingin menilai tampilan dan kemudahan akses fungsi-fungsi dalam aplikasi. 
Adapun kegiatan pembuatan rapor berbasis komputer ini dikerjakan dengan menggunakan Microsoft Excel dan VBA, disertai kegiatan sosialisasi pemakaian aplikasi. Angket pengguna berbasis CSUQ dibagikan melalui Kepala Sekolah ke setiap guru untuk dimintai pendapatnya tentang aplikasi yang dibuat. Gambar 2 menunjukkan kondisi sosialisasi di SMP YPK.

\section{HASIL DAN PEMBAHASAN}

Hasil dari kegiatan ini adalah dua aplikasi, yaitu: 1) aplikasi input nilai harian untuk guru mata pelajaran, dan 2) aplikasi rapor semester dan tahunan untuk wali kelas.

Aplikasi nilai harian digunakan oleh guru memasukkan nilai ulangan, remidi, nilai

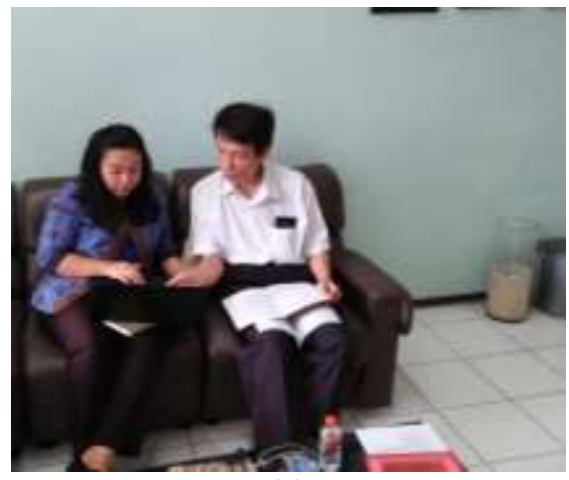

(a)

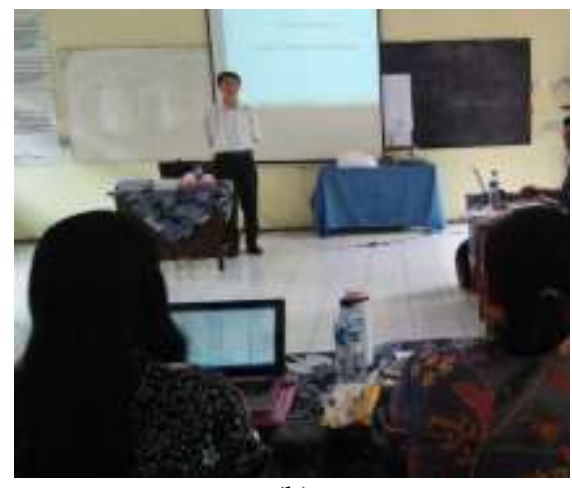

(b)

Gambar 2. a) Kegiatan Perencanaan; b) Kegiatan Sosialisasi Pemakaian Rapor Berbasis Komputer tugas (ketiganya disebut PH (Penilaian Harian), PTS (Penilaian Tengah Semester), dan PAS (Penilaian Akhir Semester). Formula yang digunakan untuk menghitung NA (Nilai Akhir), sesuai arahan sekolah adalah sebagai berikut:

untuk kelas VII dan VIII:

$$
N A=\frac{(2 x P H)+P T S+P A S}{4}
$$

khusus kelas IX, semester genap:

$$
N A=\frac{(2 x P H)+P A S}{3}
$$

Sedangkan nilai rapor diperoleh dengan formula:

Nilai rapor $=$

$40 \%$ NA semester I + $60 \%$ NA semester II

Karakteristik mata pelajaran menyebabkan ada dua jenis KKM (Kriteria Ketuntasan Minimal) yaitu 70 dan 75 . KKM 75 terdiri atas mata pelajaran: Pendidikan Agama dan Budi Pekerti, PPKn, Bahasa Indonesia, IPA, IPS, Bahasa Inggris, Seni Budaya, Pendidikan Jasmani-Olah Raga-Kesehatan (PJOK), Prakarya, dan Bahasa Mandarin. Sedangkan mata pelajaran yang memiliki KKM 70 adalah Bahasa Jawa dan Matematika.

Predikat dalam penilaian akhir mengikuti range sesuai KKM mata pelajaran tersebut, yaitu:

1) Untuk mata pelajaran dengan KKM 70: nilai A (91-100), nilai B (81-90), nilai C (70-80), dan nilai $\mathrm{D}(<70)$.

2) Untuk mata pelajaran dengan KKM 75 : nilai A (93-100), nilai B (84-92), nilai C (75-83), dan nilai $\mathrm{D}(<75)$. 


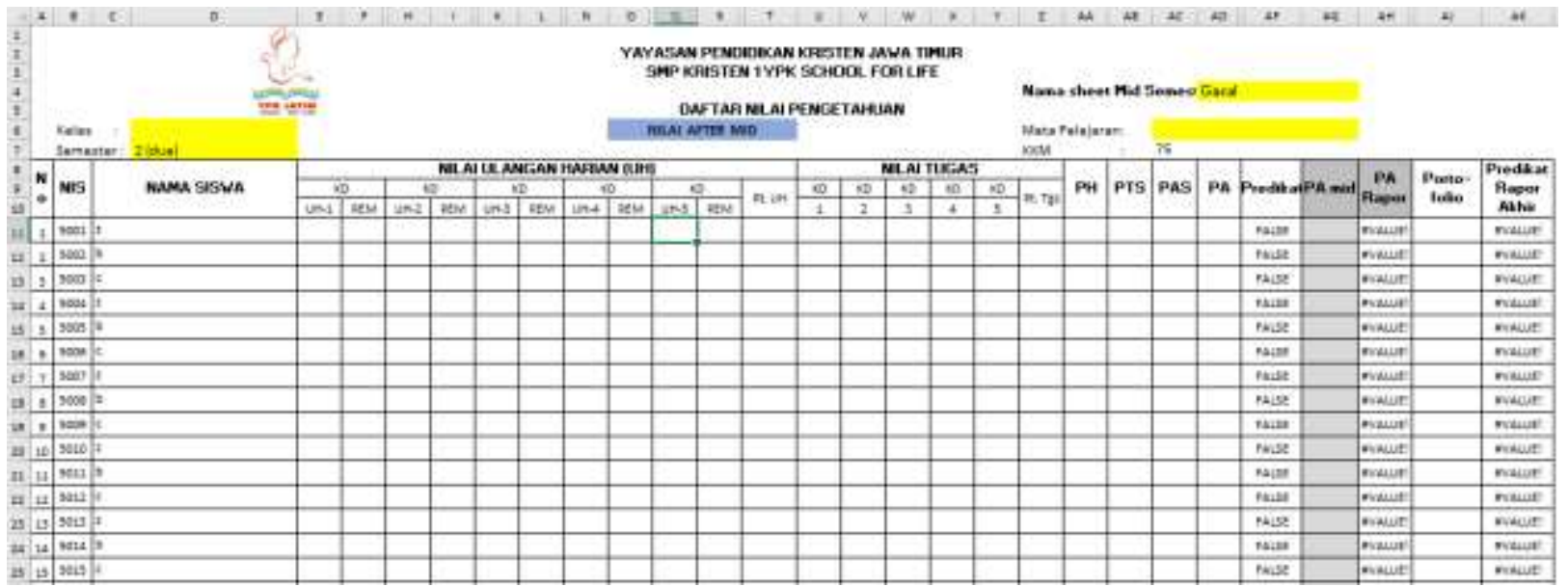

Gambar 3. Tampilan Aplikasi Input Nilai Harian

pertama yaitu aplikasi nilai harian untuk guru.

Bagian kedua dari aplikasi adalah aplikasi rapor semester dan tahunan untuk wali kelas. Aplikasi ini akan menerima daftar nilai dari setiap guru mata pelajaran. Saat ini pemasukan nilai ke aplikasi ini menggunakan cara copy-paste sheet dari guru ke aplikasi rapor. Nilai-nilai tersebut akan dikompilasi sebagai rapor di pertengahan tahun dan saat kenaikan kelas. Aplikasi ini dapat mengotomatisasi penyatuan nilai dari semua mata pelajaran ke dalam satu sheet excel yang dapat dipakai untuk rapor. Gambar 4 mengilustrasikan tampilan aplikasi rapor semester dan tahunan.

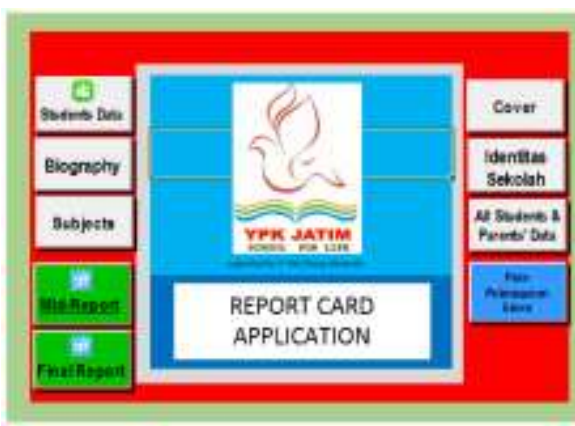

(a)

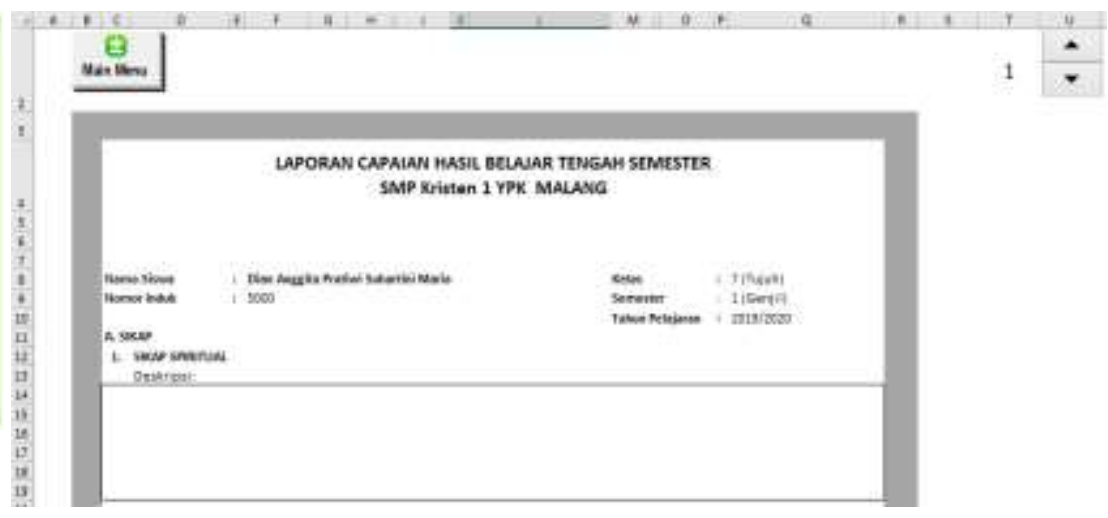

(b)

Gambar 4. a) Menu pada Aplikasi Rapor; b) Tampilan Aplikasi Rapor Semester 
Berikut adalah hasil angket dengan metode kuesioner. Kuesioner diberikan kepada pengguna aplikasi. Jumlah pengguna adalah 13 orang dan terdapat 19 pertanyaan dalam setiap kuesioner. Tabel 2 merupakan konversi jawaban item kuesioner menjadi nilai kuantitatif.

Tabel 2. Konversi Item Kuesioner menjadi Nilai Kuantitatif

\begin{tabular}{cc}
\hline Skor & Jawaban \\
\hline 5 & Sangat setuju \\
\hline 4 & Setuju \\
\hline 3 & Ragu-ragu \\
\hline 2 & Tidak setuju \\
\hline 1 & Sangat tidak setuju \\
\hline
\end{tabular}

Dari angket dihitung nilai usability dengan cara mencari nilai minimum, maksimum, dan rentang kategori penilaian. Tabel 3 menunjukkan jumlah penjawab dan skor yang didapat dari kuesioner.

Nilai tertinggi dan terendah dari data diperoleh dengan cara:

Tabel 3. Jumlah Penjawab dan Skor

\begin{tabular}{rcc}
\hline Skor & Jumlah isian & Jumlah skor \\
\hline 5 & 33 & $5 \times 33=165$ \\
\hline 4 & 161 & $4 \times 161=644$ \\
\hline 3 & 53 & $3 \times 53=159$ \\
\hline 2 & 0 & 0 \\
\hline 1 & 0 & 0 \\
\hline & Jumlah & 968 \\
\hline
\end{tabular}

Nilai tertinggi $=$ jumlah pertanyaan $\mathrm{x}$ nilai tertinggi $\mathrm{x}$ banyak responden

$$
=19 \times 5 \times 13=1235
$$

Nilai terendah $=$ jumlah pertanyaan $\mathrm{x}$ nilai terendah $\mathrm{x}$ banyak responden

$$
=19 \times 1 \times 13=247
$$

Sedangkan rentang data menjadi:

Nilai tertinggi - nilai terendah $=$

$$
=1235-247=988
$$

Panjang kelas diperoleh dari:

Rentang data/jumlah kategori penilaian $=$

$$
=988 / 5=197
$$

Dari perhitungan nilai minimum, nilai maksimum, dan panjang kelas maka diperoleh kategori penilaian seperti pada Tabel 4.

Dari Tabel 3 diperoleh jumlah skor adalah 968. Jika disepadankan dengan Tabel 4, maka faktor kualitas usability aplikasi yang dibuat masuk dalam kategori "Layak." Nilai kuantitatif kelayakan dihitung dengan persentase: $(968 / 1235)$ x $100 \%=78.4 \%$.

Tabel 4. Kategori Penilaian Usability dalam Kegiatan

\begin{tabular}{l|l}
\hline \multicolumn{1}{c|}{ Interval nilai } & \multicolumn{1}{c}{ Kategori } \\
\hline $247-444$ & Sangat tidak layak \\
\hline $445-642$ & Tidak layak \\
\hline $643-840$ & Cukup layak \\
\hline $841-1038$ & Layak \\
\hline $1039-1235$ & Sangat layak \\
\hline
\end{tabular}

Analisis berikutnya dilanjutkan dengan analisis data untuk uji hipotesis. Hipotesis nol dalam kegiatan ini adalah tidak adanya perbedaan yang signifikan antara ketiga kategori dalam angket, yaitu SYSUSE, INFOQUAL, dan INTERQUAL.

Uji normalitas data dengan ShapiroWilk test menunjukkan data tidak terdistribusi normal $(p=0.0005)$. Pengujian hipotesis dengan analisis non- parametrik Kruskal-Wallis test menyimpulkan bahwa ada perbedaan nilai (value) hasil angket antara ketiga kategori pertanyaan, $\chi^{2}(2)=$ $16.765, p=0.0005)$. Dimana mean rank nilai angket adalah 133.68 untuk SYSUSE, 100.18 
untuk INFOQUAL, dan 114.76 untuk INTERQUAL.

Berikutnya post-hoc tes dengan Mann Whitney U digunakan untuk mengetahui perbedaan pasangan kategori. Hasil yang diperoleh sebagai berikut: uji beda per pasangan bahwa nilai angket pada kategori SYSUSE lebih besar secara signifikan daripada kategori INFOQUAL ( $U=3369.5$, $p=0.0005)$. Tetapi pada kedua pasang yang lain yaitu SYSUSE dan INTERQUAL ( $U=$ 1707.5, $p=0.072$ ) maupun INFOQUAL dan INTERQUAL $(U=1561, p=0.218)$; tidak menunjukkan perbedaan nilai angket yang signifikan.

Hal tersebut menunjukkan bahwa aplikasi memberikan kepuasan lebih secara signifikan pada penggunanya di kategori SYSUSE (system usefulness). Hal tersebut menandakan bahwa aplikasi yang dibuat berguna bagi pengguna dalam menyelesaikan tugasnya. Namun kurangnya pesan-pesan error jika pengguna melakukan kesalahan operasi (INFOQUAL) ataupun kualitas interface (INTERQUAL) perlu ditingkatkan untuk pengembangan selanjutnya; dengan harapan memiliki mean rank yang tinggi dan tidak berbeda secara signifikan terhadap INFOQUAL.

\section{PENUTUP}

\section{Simpulan}

Kegiatan ini menghasilkan aplikasi rapor semester dan pencatatan nilai harian siswa SMP YPK, Malang; yang merupakan wujud pengimplementasian ipteks untuk masyarakat. Format penilaian harian maupun rapor telah mengimplementasikan kebutuhan pengguna sesuai Kurikulum 2013. Pengembangan aplikasi menggunakan metode spiral. Sedangkan hasil evaluasi usability menunjukkan bahwa aplikasi tergolong layak (memiliki nilai kuantitatif kelayakan $78.4 \%$ ). Hasil pengujian lain dengan angket The Computer System Usability Questionnaire (CSUQ) menunjukkan bahwa aplikasi memiliki mean rank SYSUSE (system usefulness) yang besar. Hal tersebut menandakan bahwa aplikasi yang dibuat berguna bagi pengguna dalam menyelesaikan tugasnya. Berdasarkan hasil angket, aplikasi perlu meningkatkan kategori kualitas interface atau tampilan

\section{Ucapan Terima Kasih}

Terima kasih kepada Kepala Sekolah SMP YPK, wali kelas VII, VIII, dan IX, serta para guru di SMP YPK yang telah mendukung kegiatan ini. Demikian juga ucapan terima kasih kepada LPPM, Universitas Ma Chung yang memberi dukungan sehingga selesainya program ini.

\section{E. DAFTAR PUSTAKA}

Boehm, B. W. 1988. A spiral model of software development and enhancement. Computer, 21(5), 61-72.

Erdinç, O., \& Lewis, J. R. 2013. Psychometric Evaluation of the TCSUQ: The Turkish Version of the Computer System Usability Questionnaire. International Journal of Human-Computer Interaction, 29(5), 319-326.

Kemendikbud. 2012. Dokumen kurikulum 2013. Kementerian Pendidikan Dan Kebudayaan, 1-23.

Lewis, J. R. 1995. IBM Computer Usability Satisfaction Questionnaires: Psychometric Evaluation and Instructions for Use. Int. J. Hum. Comput. Interaction, (1).

Lewis, J. R. 2018. Measuring Perceived Usability: The CSUQ, SUS, and UMUX. International Journal of 
Human-Computer Interaction, 34(12), 1148-1156.

Sinambela, P. N. J. M. 2013. Kurikulum 2013 dan Implementasinya dalam Pembelajaran. E-Journal Universitas Negeri Medan, 6, 17-29.

Siswanto. 2017. Strategi Mengimplementasikan Kurikulum 2013 pada Proses KBM. Mitra Karyapena. 